


\title{
Prevalence of clinical bovine dermatophilosis in dairy cattle in selected district towns of West Shewa Zone, Oromia Regional State, Ethiopia
}

\author{
Edilu Jorga Sarba* and Bizunesh Mideksa Borena \\ Ambo University College of Agriculture and Veterinary Science, Department of Veterinary Labora- \\ tory Technology \\ *Corresponding author: jedilu8@gmail.com/jorgae@yahoo.com,Tel.+251911957036 \\ https://dx.doi.org/10.4314/evj.v21i1.7
}

\begin{abstract}
A cross-sectional study was conducted from June, 2013 to October, 2014 to determine the prevalence and associated risk factors of clinical bovine dermatophilosis in dairy cattle in selected districttowns of West Shewa Zone. A total of 816 dairy cattle from 60 dairy farms were clinically examined for skin lesion followed by microscopic examination of skin scrapings. The overall individual animal and herd level prevalence of clinical dermatophilosis were 5.0\% and $18.3 \%$, respectively. Agro-ecology, management system,ecto-parasite infestations were risk factors significantly associated with its occurrence. Consequently, the prevalence was significantly higher in cattle in mid land altitude than cattle in highlands; in cattle under semi-intensive than in intensive management system and in ecto-parasite infested than non-infested ones. However, other studied variables such as herd size, age, sex and breed did not show significant associations $(p<0.05)$ with the disease. These findings indicate the interactions of the risk factors for the occurrence of clinical dermatophilosis in the study area. Consequently, clinical dermatophilosis might have adverse effects on production and productivity of dairy cattle. Therefore, good husbandary practices such as control of ecto-parasite and proper therapeutic intervention are of paramount importance for control of clinical bovine dermatophilosis and to reduce lossess associated to the disease.
\end{abstract}

Keywords: Clinical dermatophilosis; Dairy cattle; Prevalence; Risk factors

\section{Introduction}

Ethiopia is among the developing countries,whose economy is reliant on agriculture and about 80-85 percent of the peoples are engaged in crop and live- 
stock farming (ILRI, 2013). The huge livestock resource in Ethiopia is known to have a significant contribution to the national economy, though the productivity in terms of meat and milk per animal is very low. This is due to a number of factors among which livestock diseases, inadequate feeding, low genetic potential of indigenous breeds and the low input traditional livestock management practices are the most important ones (Yoseph Shiferaw et al., 2003). In the recent decade, dairy production in Ethiopia is evolving from a completely extensive production system using indigenous cattle to market oriented milk production using cross breed especially in urban and peri-urban areas of major towns. However, compared to the our indigenous cattle which have resistance to different tropical diseases, the extotic cattle breed as well as their crosses are more susceptable to those diseases. Thus the dairy production using these crossbred cattle is constrained by diseases that cause morbidity and mortality (Azage Tegegn et al., 2001).

Bovine dermatophilosis is one of the disease swhich are economically important in dairy cattlebreed (Moges Woldemeskel and Girma Taye, 2002). It is an acute or chronic exudative, pustular dermatitis caused by bacterium Dermatophilus congolensis (OIE, 2008). D. congolensis is a gram positive facultative anaerobic actinomycete and an obligate invader of the skin of cattle and other species (Radostitset al., 2007). The dermatophilosis infection is clinically observed in 3 stages: first stage lesion appears as nodule formation and exudation; stage two as scab formation and coalition of initial lesions and stage three as lesions characterized by accumulation of cutaneous keratinized materials (wart-like lesion) (Fraser et al., 2008). Thick crusts or scabs, which comes away easily with tuft of hair leaving a moist, depressed area with bleeding points from capillaries is characteristic of lesions of dermatophilosis (Quinn et al.,1999).

The actual time when bovine dermatophilosis was introduced to Ethiopia is not known, however, its presence was confirmed by different workers (Yeruham et al., 1995; Temesgin Samuel et al., 1998; Moges Woldemeskel 2000; Enquebaher Kassaye et al., 2003). The disease causes reduction of productivity and hide and skin quality and death and culling of affected cattle (Chatikobo et al., 2004). However, published reports on bovine dermatophilosis relatively scarce and the epidemiological investigation done in both intensive and extensive production systems is not sufficient, which is indicative of limited attention given to the disease (Enquebaher Kassaye et al., 2003). In West Shewazone of Oromia region where small holder dairy farming is growing, personal 
observation and complaints from dairy owners showed the presence of cattlewith chronic skin lesion that led to loss of milk yield, death and culling of valuable cows. Moreover the level of the disease was yet not investigated in this region and information regarding bovine dermatophilosis is lacking especially in dairy farms which are in promising development. Therefore, the objective of this study was to investigate the status of clinical bovine dermatophilosis and risk factors involved in dairy cattle in selected districts towns of West Shewa zone of Oromia regional state.

\section{Materials and Methods}

\section{Description of the study area}

The study was conducted from June, 2013 to October, 2014 in West Shewa zone of Oromia Region, in selected towns namely; Holeta, Ejere, Ginch, Ambo and Guder which are located at 40,50, 90, 114 and 126kms west of Addis Ababa on the way from Addis Ababa to Nekemte, respectively (Fig. 1). Ambo is the administrative center of the Zone. The selected towns lie with the altitude ranges of 2,391 (Holeta) to 2,101 (Guder) m.a.s.l. The mean annual temperature ranges between $22^{\circ} \mathrm{C}$ (Guder) to $15.9^{\circ} \mathrm{C}$ (Holeta) and the rain fall ranges between 900-1300mm (Yazachew Etefa and Kasahun Dibaba, 2011).

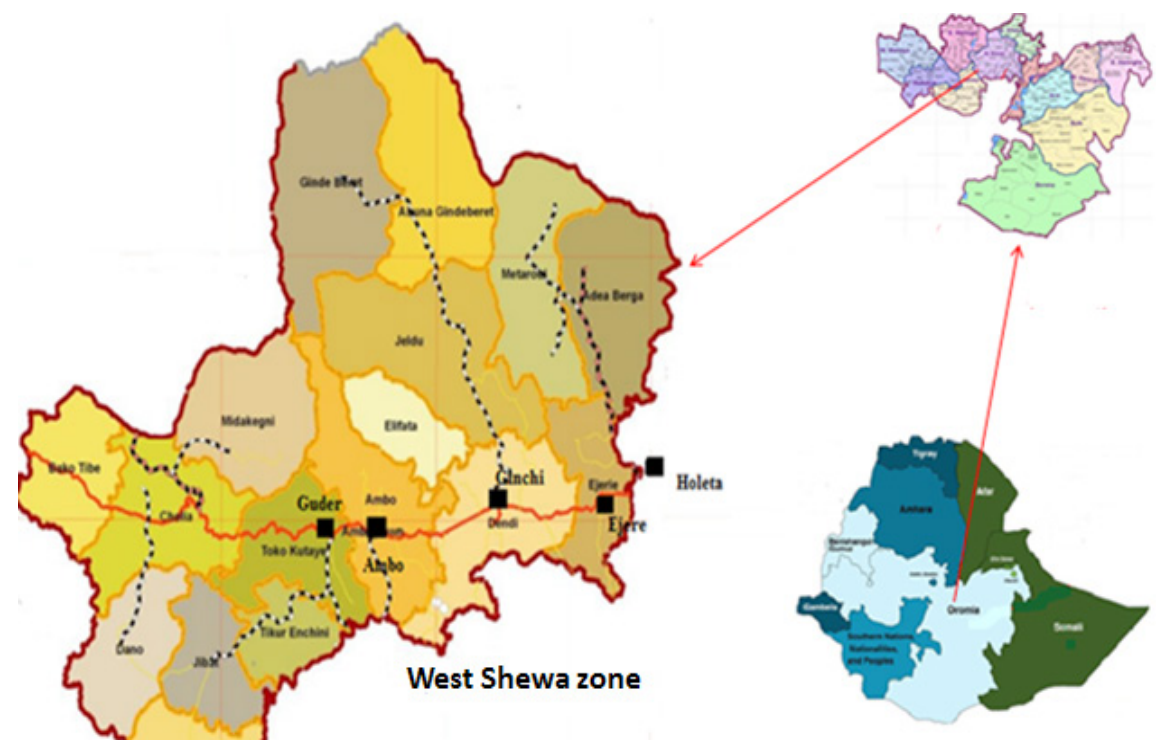

Fig. 1. Map of West Shewa zone showing study towns 


\section{Study animals}

The study animals were dairy cattle of age above 6 months and breed (cross and indigenous); which were kept for milk production belonging to volunteer dairy farmer/farm owners. Cattle kept either under smallholder or larger dairy farm, managed in either intensive or extensive system were included in this study.

\section{Sample size and sampling techniques}

Since there was no previous report on its prevalence in dairy cattle in the zone, $50 \%$ prevalence and $5 \%$ precision were used to calculate the sample size (Thrusfield, 2005). Though the calculated sample size was 384, for the purpose of increasing precision 816 dairy cattle were investigated from 60 farms. Study towns were purposively selected based on the availability of dairy farms and the farms were chosen based on owner's voluntariness. The total sample size was partitioned to each selected town based on the dairy cattel population. However, due to the limited number of dairy farms in the study sites, all dairy farms owned by volunteer owners were considered for the study. All cattle above 6 months of age found in the sampled dairy farms were included in the study.

\section{Study design}

Cross-sectional study was conducted using clinical observation and direct microscopy. Information regarding herd structure, management system, and history of dermatophilosis in the farm, treatment response and practices of ectoparasite control in each selected dairy farms were recorded on format prepared for this purpose. Age of study animals were determined as per Samui and Jones (1990) and animals were categorized into age groups as young (above 6 months to 3 years old: upto first parity for heifers and upto first serving for males) and adult (above 3 years old). Other categories inlcude sex as male and female and breed as $<50 \%$ cross of Holstein Friesian, $>50 \%$ cross of Holstein Friesian and indigenous breed. Information regarding the exotic blood level was obtained from owners and artificial inseminators recoreds. Dairy farms were also classified as intensive, semi-intensive and extensive and herd size as less than 30 cattle per herd and greater than 30 cattle per herd. Study towns that lie in the altitude range above 2300 m.a.s.l (Holeta and Ejere) were considered as 
highland and those laying between 1500 to 2300 m.a.s.l as midaltitude (Ambo, Guder and Ginchi) as per Alemayehu Mengistu (2006).

Observational data: Animals were inspected and palpated to assess the presence of skin lesion and ecto-parasite infestation.Cattle with lesion characterized by erythema, nodular formation, exudation, loss of hair, thickening of skin and scab/crust formation were suspected for clinical dermatophilosis.

Laboratory assay: Skin scrapings were collected from suspected animals for direct microscopy in dry sterile petri-dish. The samples were emulsified in a sterile saline solution on a microscope slides, air dried, fixed with absolute methanol and stained with Giemsa at veterinary laboratory of Ambo University. The smears were then examined under the microscope (oil emersion at 100x magnification) for muti-planer septate bodies, which is typical for D.congolensis. Negative samples were examined several times including re-sampling in some cases. In addition skin scrapings and hair plucks were subjected for detection of mites and fungal spores to completely exclude dermatophilosis.

\section{Data management and analysis}

Data were entered in to Microsoft excel sheet and analyzed using STATA version11.0 statistical software(Stata Corp., College Station, TX, USA). The output variable was the status of clinical dermatophilosis, whereas the risk factors namely; district towns, breed, management system, sex, herd size, age, and tick and lice infestation were considered as explanatory variables. Descriptive statistics was used to summarize the data. Statistical association was tested using logistic regressions. Those non-collinear variables with $p$-value less than 0.25 by univariable analysis were further analyzed by a multivariable logistic regression. Odds ratio was used to see degree of association and confidence level was held at $95 \%$ and significance was at $\mathrm{p}<0.05$.

\section{Results}

\section{Prevalence of clinical bovine dermatophilosis}

Out of 816 cattle examined $7.8 \%$ were with lesion characterized by nodular growth, erythema, loss of hair, abscess, scab formation, thickening of the skin and exudations other than grossly observable ecto-parasite (tick and lice). 
Among animals with the skin lesions, $64.06 \%$ were positive for dermatophylosis. The overall prevalence of the dermphylosis was found to be $5.0 \%$ and $18.3 \%$ at individual aniamal and herd level, respectively (Table1).

Table 1. Individual and herd level prevalence of clinical bovine dermatophilosis

\begin{tabular}{lccccc}
\hline $\begin{array}{l}\text { District } \\
\text { towns }\end{array}$ & $\begin{array}{l}\text { No animals } \\
\text { examined }\end{array}$ & $\begin{array}{l}\text { Prevalence of } \\
\text { skin lesion }\end{array}$ & $\begin{array}{l}\text { Animal level } \\
\text { prevalence of } \\
\text { dermatophilosis }\end{array}$ & $\begin{array}{l}\text { No herd } \\
\text { tested }\end{array}$ & $\begin{array}{l}\text { Herd level } \\
\text { Prevalence }\end{array}$ \\
\hline Ambo & 277 & $35(12.6 \%)$ & $26(9.4 \%)$ & 20 & $3(15.0 \%)$ \\
Holeta & 285 & $26(9.1 \%)$ & $10(3.5 \%)$ & 15 & $6(40.0 \%)$ \\
Guder & 116 & $5(4.3 \%)$ & $3(2.6 \%)$ & 8 & $1(12.5 \%)$ \\
Ejere & 100 & $4(4.0 \%)$ & $1(1 \%)$ & 9 & $1(11.1 \%)$ \\
Giinchi & 38 & $3(7.9 \%)$ & $1(2.6 \%)$ & 8 & $1(12.5 \%)$ \\
Total & 816 & $64(7.8 \%)$ & $41(5.0 \%)$ & 60 & $11(18.3 \%)$ \\
\hline
\end{tabular}

Among the risk factors agro-ecology, management system and tick and lice infestation showed significant association $(\mathrm{p}<0.05)$ with clinical dermatophilosis. Accordingly, cattle from Ginchi, Ambo and Guder (mid altitude) were at risk of dermatophilosis infection $(\mathrm{p}<0.05, \mathrm{OR}=2.805)$ than cattle from Holeta and Ejere (highland). Dermatophilosis was more prevalent $(\mathrm{p}<0.05, \mathrm{OR}=2.43)$ in cattle under semi-intensive management system than in the intensively managed dairy farms. Similarly, significantly higher risk of clinical dermatophilosis was observed in ecto-parasite infested cattle $(p<0.001, \mathrm{OR}=9.955)$ than non-infested ones. The rest of the studied factors such as herd size, age, sex and breed did not show significant association $(p>0.05)$ with the clinical bovine dermatophilosis (Table 2). 
Table 2. Univariable logistic analysis of association of risk factors and prevalence of clinical bovine dermatophilosis

\begin{tabular}{|c|c|c|c|c|c|c|}
\hline \multirow[t]{2}{*}{ Variable } & \multirow[t]{2}{*}{ Level } & \multirow[t]{2}{*}{$\mathbf{N}$} & \multirow{2}{*}{$\begin{array}{c}\text { Dermatophilosis } \\
\text { positive }(\%)\end{array}$} & \multicolumn{3}{|c|}{ Univariable analysis } \\
\hline & & & & p-value & OR & $95 \% \mathrm{CI}$ \\
\hline \multirow{2}{*}{$\begin{array}{l}\text { Agro-ecological } \\
\text { category }\end{array}$} & Midland & 431 & 30 & - & - & - \\
\hline & High land & 385 & 11 & 2.805 & 0.004 & $1.35-5.82$ \\
\hline \multirow{3}{*}{$\begin{array}{l}\text { Management } \\
\text { System }\end{array}$} & Intensive* & 401 & $12(3.0)$ & - & - & \\
\hline & $\begin{array}{l}\text { Semi- } \\
\text { intensive }\end{array}$ & 358 & $26(7.3)$ & 0.013 & 2.43 & $1.20-4.92$ \\
\hline & Extensive & 57 & $3(5.3)$ & 0.374 & 1.80 & $0.49-6.58$ \\
\hline \multirow[t]{2}{*}{ Herd size } & $<30$ cattle* & 417 & $20(4.8)$ & - & - & - \\
\hline & $>30$ cattle & 399 & $21(5.3)$ & 0.76 & 1.103 & $0.58-2.07$ \\
\hline \multirow[t]{2}{*}{ Age } & Young & 326 & $13(4.0)$ & - & - & - \\
\hline & Adult & 490 & $28(5.7)$ & 0.271 & 1.46 & $0.74-2.86$ \\
\hline \multirow[t]{2}{*}{ Sex } & Female* & 756 & $37(4.9)$ & - & - & - \\
\hline & Male & 60 & $4(6.7)$ & 0.545 & 1.39 & $0.48-4.03$ \\
\hline \multirow[t]{3}{*}{ Breed } & $>50 \% \operatorname{cross}^{*}$ & 446 & $15(3.4)$ & - & - & - \\
\hline & $<50 \%$ cross & 318 & $26(8.2)$ & 0.852 & 0.01 & $1.33-4.91$ \\
\hline & Local & 52 & $0(0)$ & - & - & - \\
\hline \multirow[t]{2}{*}{ Ecto-parasite } & Infested & 148 & $27(18.2)$ & - & - & - \\
\hline & Non-infested & 668 & $14(2.1)$ & 9.955 & 0.000 & $\begin{array}{l}5.054- \\
19.609\end{array}$ \\
\hline
\end{tabular}

Key, * reference category, $\mathrm{N}=$ number of animals examined, $\mathrm{CI}=$ confidence interval, $\mathrm{OR}=$ odds ratio

Agro-ecology, management system, and ecto-parasite infestation were the only risk factors with $\mathrm{p}<0.25$ by univariale analysis, which were subjected to multivariable logistic regression analysis. Accordingly, these three factors were also showed significant association by multivariable logistic resgression analysis $(\mathrm{p}<0.05)$ (Table 3). 
Table 3. Multivariable logistic analysis of the risk factors with clinical bovine dermatophilosis

\begin{tabular}{|c|c|c|c|c|c|c|}
\hline \multirow[t]{2}{*}{ Variable } & \multirow[t]{2}{*}{ Level } & \multirow[t]{2}{*}{$\mathbf{N}$} & \multirow{2}{*}{$\begin{array}{l}\text { No } \\
\text { positive } \\
(\%)\end{array}$} & \multicolumn{3}{|c|}{ Multivariable analysis } \\
\hline & & & & p-value & OR & $95 \%$ CI \\
\hline \multirow{2}{*}{$\begin{array}{l}\text { Agro-ecological } \\
\text { category }\end{array}$} & Highland* & 385 & $11(2.6)$ & - & - & - \\
\hline & Midland & 431 & $30(7.8)$ & 0.010 & 2.790 & $1.284-6.064$ \\
\hline \multirow{3}{*}{$\begin{array}{l}\text { Management } \\
\text { System }\end{array}$} & Intensive* & 401 & $12(3.0)$ & - & - & - \\
\hline & Semi-intensive & 358 & $26(7.3)$ & 0.053 & 0.15 & $0.02-1.03$ \\
\hline & Extensive & 57 & $3(5.3)$ & 0.026 & 0.07 & $0.01-0.72$ \\
\hline \multirow[t]{2}{*}{ Ecto-parasite } & Non-infested $*$ & 668 & $14(2.09)$ & - & - & - \\
\hline & Infested & 148 & $27(18.24)$ & 0.000 & 13.974 & $\begin{array}{l}5.981- \\
32.650\end{array}$ \\
\hline
\end{tabular}

Key, ${ }^{*}$ reference category, $\mathrm{N}=$ number of animals examined, $\mathrm{CI}=$ confidence interval, $\mathrm{OR}=$ odds ratio

\section{Clinical observation findings}

Clinical examination of dermatophilosis cases revealed various stages of lesions on different location over the body. Initially lesions appear as small nodular growth (Fig1 B), which progress to exudation, often with raised or matted hairs and crust (Fig3, A, Fig1 A and Fig2 A\&B). Chronic lesions were frequently hyperkeratotic with coalition of initial crusts (Fig3 B). Lesions were observed on the head region (muzzle and ear) and neck (Fig1), udder/ teat and perineal area (Fig2), legs (Fig3) and back and sides of the body. In all the cases lesions were non-itching and up on removal of the thick scabs it showed a characteristic concave underside leaving a raw bleeding epidermis.All cattle with chronic dermatophilosis were complained for poor response to treatment (penicillin, streptomycin and oxytetracycline) and the disease remains as seasonally relapsing skin lesion causing reduction of milk yield, loss of weight and market value, unexpected culling and death. 

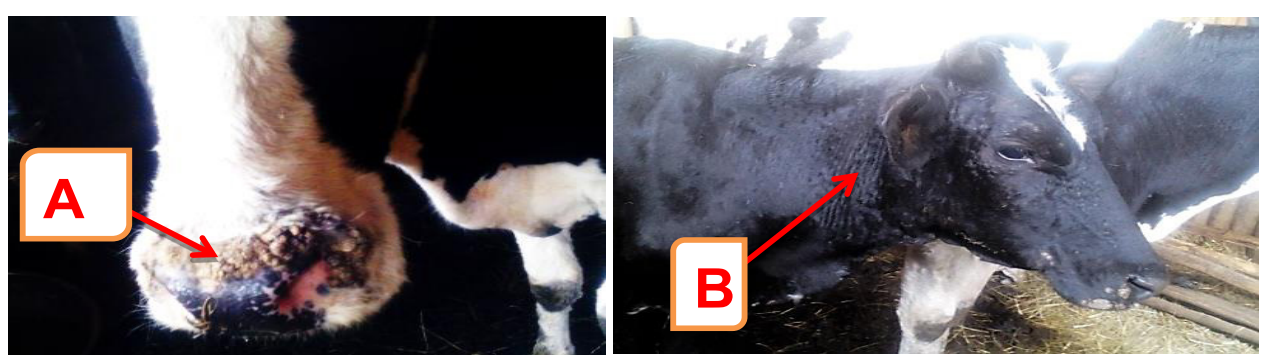

Fig 1. Dermatophilosis lesion on the head region/muzzle (A) and neck (B) of 2year old heifers
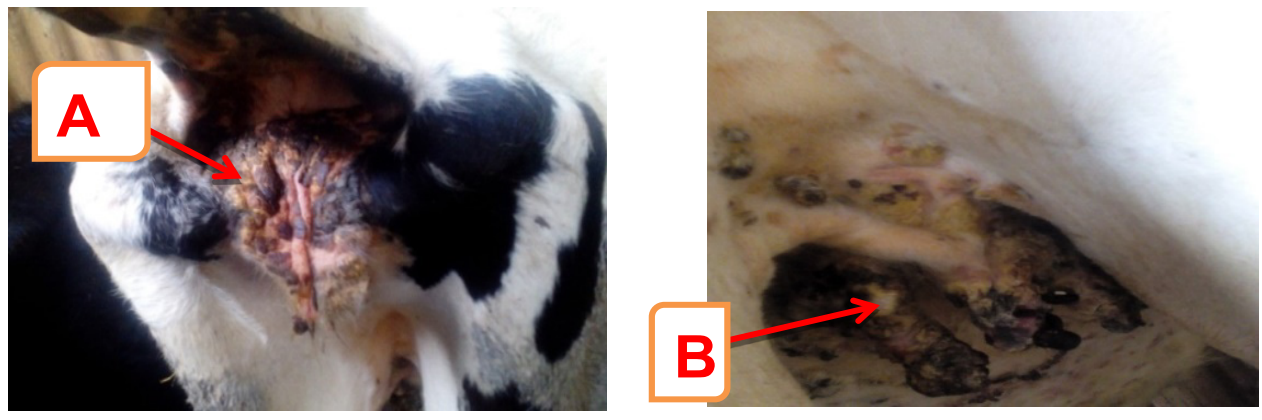

Fig 2. Dermatophilosis affected 2 years heifers showing lesion on perineal area and udder/tea
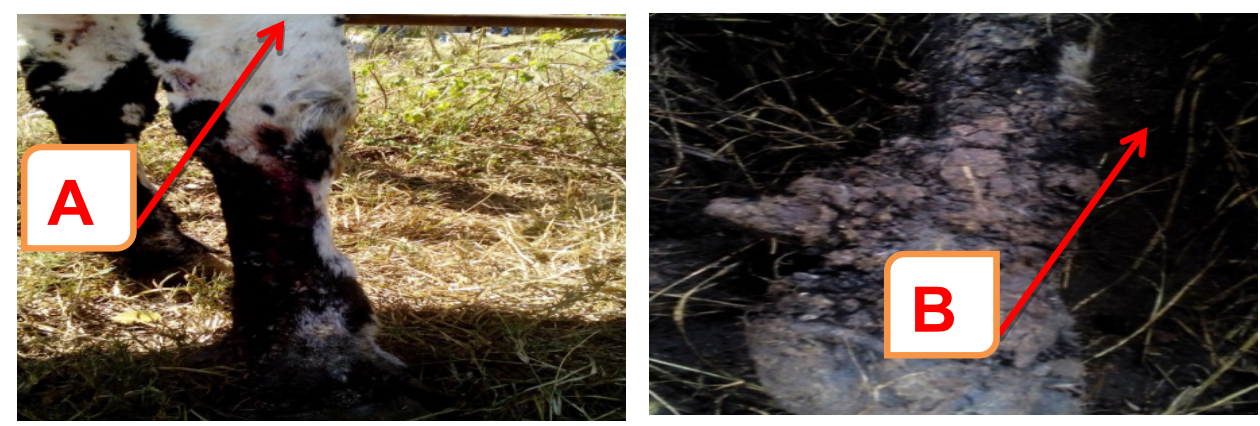

Fig 3. Forelimb of dermatophilosis affected heifers showing erythema (A) and characteristic hyperkeratosis (B) 


\section{Discussion}

The overall prevalence of clinical bovine dermatophilosis obtained in this study was 5\% which is comparable with the result of Della Berhanu and Moges Woldemeskel (1999), Moges Woldemeskel (2000) and Enquebaher Kassaye et al (2003) from Ethiopia who reported 5.1\%, 4.8\% and 5.22\% respectively. The current finding is relatively higher than $1.56 \%$ and $1.04 \%$ report of Addise Ambilo and Achenef Melaku (2013) and Meseret Admassu and Sefinew Alemu (2011), respectively, but lower than $8.7 \%$ and $15.2 \%$ reports by Awadet al (2008) from Egypt and Moges Weldemeskel and Girma Taye (2002) from highland of eastern Ethiopia, respectively. The variation in the prevalence of dermatophilosis among the reports might be due to the difference in study setup, such as breed of cattle studied and their management system and season. Relatively higher prevalence of dermatophilosis in the present study could be due to the reason than the study was conducted during the wet season, as high moisture weakens the skin barrier, facilitates germination, maturation and release of zoospores from the preexisting lesions and their subsequent cutaneous penetration, which initiated appearance of clinical cases and facilitates maintenance of the disease (Radostitis et al., 2007; Fraser et al., 2008).

In this study the prevalence of clinical dermatophilosis was found significantly higher in cattle from highlands as compared to those from midland. This could be associated with the relatively the humid warm climate and high population of ecto-parasite in crossbred cattle in midland climatic condition and the presence of chronic carrier cows in some private and government owned dairy farms in the area. The significantly higher prevalence $(p<0.05)$ of dermatophilosis in semi-intensive management system as compared to cattle in intensive systemis in agreement with Babul et al (2010). This could be due to exposure of cattle to thorny bushes, contaminated area, prolonged rain and poor ectoparasites control practice in this system. Moreover, earlier reports by Koney et al (1996) and Della Berhanu and Moges Woldemeskel (1999) showed higher prevalence of dermatophilosis in cattle kept under traditional management systems in Ghana and central Ethiopia, respectively. They all argued value of improved management in reducing the prevalence of dermatophilosis, even in highly susceptible animals.

This study indicated zero prevalence in indigenous cattle as compared to $5.2 \%$ in cross breed cattle, which is in line with lower prevalence of dermatophilo- 
sisreported in indigenous cattle as compared to exotic breeds and their crosses by Moges Woldemeskel (2000) (3.2\% vs. 26.9\%), Della Berhanu and MogesWoldemeskel (1999) (4.8\%vs. 12.8\%), and Meseret Admassu and Sefinew Alemu (2011) (0.66\%vs. 5.45\%) though there is sampling disproportion. The higher prevalence in crossbred cattle may be due poor management of such animals and their lower immunity level in the tropical environment.However, these finding disagrees with Moges Woldemeskel and GirmaTaye (2002) who reported higher frequency (15.04\%) of dermatophilosis infection in indigenous cattle. Della Berhanu and Moges Woldemeskel (1999) and Meseret Admassu and Sefinew Alemu (2011) reported higher prevalence of dermatophilosis in adult than younger animals which was in agreement with our finding, though the difference is not significant. The numerically higher prevalence in younger than adults cattle could be associated with prolonged exposure to risk factors indicated elsewhere. Ecto-parasite like and live infestation is strongly associated with the occurrence of extensive lesions of Dermatophilosis (Enquebaher Kassaye et al., 2003; Fraser et al., 2008). In line with this the present study revealed significantly higher $(\mathrm{p}<0.001)$ prevalence of dermatophilosis in ecto-parasite infested cattle (19.9\%) than in non-infested ones. Reports have described that ticks cause mechanical injury to the skin, which aid entry of zoospores (Msami et al., 2001).

In this study clinical lesions of Dermatophilosis were noted on the neck, head region, back and sides of the body and legs which is very similar to the observation of Siva Prasad and Vijaya Sailaja (2015). In addition, lesions were observed on the perineal area and udder. Moreover, lesions resulted in irreversible damage to teat, the consequence of which is involuntary culling of dairy cattle.The lesions observed varied from minor localized to generalized, covering the whole surface of the body. Characteristically, lesions varied from erythema tothick scab formation which coalesces to form cutaneous keratinized wart-like lesions. This is in agreement with varies investigators (Radostits et al., 2007; Fraser et al., 2008).

In conclusion,the gross clinical features and the typical bacteriain stained smears evidenced clinical bovine dermatophilosis and the prevalence was noticeable in this study.It was found to be more associated with cattle of highland, cattle managed under semi-intensive system and with poor ecto-parasite control. Indeed, these were the influencing factors for the occurrence and maintenance of clinical dermatophilosis in dairy cattle in the area. Consequently, clinical dermatophilosis will have higher economic losses through loss 
of productivity, cost of treatment and death of dairy cattle and hence demands serious attention. Therefore, this study showed the necessity of good management such as control of ecto-parasite in cattle under semi-intensive system and proper therapeutic management of clinically sick animals to control clinical bovine dermatophilosis.

\section{References}

Admasu, M. and Alemu, S., 2011. Study on the clinical bovine dermatophilosis and its potential risk factors in north western Ethiopia. Int. J. Anim. Vet. Adv., 3, 33-36.

Ambilo, A. and Melaku, A., 2013. Major skin diseases of cattle: prevalence and risk factors in and aroundHawassa, Southern Ethiopia. J. Adv. Vet. Res., 3,147-153.

Awad, W. S., Nadral-Elwgoud, M.,Abdou, I. and El-Sayed, A. A., 2008.Diagnosis and treatment of bovine, ovine and equine dermatophilosis. J. Appl. Sci. Res., 44,367374.

Tegegn A., Tsehay, R., Alemu, G. and Hizkias, K., 2001. Milk recording and herd registration in Ethiopia. In:Proceedings of the $8^{\text {th }}$ Annual Conference of the Ethiopian Society of Animal Production (ESAP), 24-26 August 2000, Addis Ababa, Ethiopia.

Babul, D.N., Shamim, A., SiddiqurRahman and FazlulHuque,AKM., 2010. Prevalence and therapeutic management of bovine dermatophilosis. Bangladesh Res. Pub. J., 4(3), 198-207.

Berhanu, D. and Woldemeskel, M., 1999. Bovine dermatophilosis and its influencing factors in central Ethiopia. J. Vet. Med., 46, 593-597.

Chatikobo, P., Kusina, N. T., Hamudikuwanda, H. and Nyoni, O., 2004. A monitoring study of the prevalence of dermatophilosis and parafilariosis in cattle in a smallholder farming area in Zimbabwe.Trop. Anim. Hlth. Prod., 36 (3), 207-215.

Etefa,Y. and Dibaba,.K. 2011. Physical and Socio Economic Profile of West Shewa Zone and Districts'. Bureau of Finance and Economic Development Regional Data and Information core Process Organized by Regional Socio Economic Profile Experts; The National Regional Government of Oromia, January 2011 Finfinne

Fraser, C.M., Bergeron, J.A. and Aiello, S.E., 2008. The Merck Veterinary Manual: A handbook of diagnosis, therapy, disease prevention and control for the veterinarian. Merck \& Co., Inc. Press, USA. Pp. 690-691.

ILRI, 2013. Smallholder dairy production and marketing systems in Ethiopia: IPMS experiences and opportunities for market-oriented development. Working Paper No. 31, Addis Ababa Ethiopia. 
Kassaye, E., Moser, I. and Woldemeskel, M., 2003. Epidemiological studies on clinical bovine dermatophilosis in Northern Ethiopia. Dtsch Tierarztl Wschr., 110, 422425.

Koney, E.B.M., Morrow, A.N. and Heron, I.D., 1996. The association between Amblyommavariegatum and Dermatophilosis: epidemiology and immunology. Trop. Anim. Hlth Prod., 28,18-25.

Mengistu, A. 2006. Country Pasture/Forage Resource Profiles. Food and Agriculture Organization, 2006.

Msami, H.M., Khascagi, D., Schopl, K., Kapaga, A.M. and Shitahara.T., 2001.Dermatophiluscongolensis in goats in Tanzania.Trop. Anim. Hlth. Prod., 33, 367-377.

OIE, 2008. Dermatophilus congolensis: A Manual of Diagnostic tests for Terrestrial Animals, $5^{\text {th }}$ edition, Office of International des Epizootics, Paris.

Quinn, P.J., Carter, M.E., Markey, B.K. and Carter, G.R., 1999. Clinical Veterinary Microbiology. Harcourt Publishers Ltd., Edinburgh, London, Pp. 153-155.

Radostits, O.M., Gray, C.G., Hinchcliff, K.W. and Constable, P.D., 2007. Veterinary Medicine: A Text Book of the Disease of Cattle, Horses, Sheep, Pigs, and Goats. $10^{\text {th }}$ edition, Saunders Elsevier, London, Pp.1048-1051.

Samuel, T., Tareke, F.,Wirtu, G. and Kiros, T., 1998. Bacteriological study of Ethiopian isolates of Dermatophilus congolensis. Trop. Anim. Hlth. Prod., 30, 145-147.

Samui, K.L. and Hugh-Jones, M.E., 1990.The epidemiology of bovine Dermatophilosis in Zambia.Vet. Res. Commun., 14, 267-278.

Shiferaw, Y., Tenhagen, B. A., Bekena, M. and Kassa, T., 2003. Reproductive performance of crossbred dairy cows in different production systems in central high lands of Ethiopia. Trop. Anim. Hlth. Prod., 25, 551-561.

Siva Prasad, B. and Vijaya Sailaja A., 2015.Prevalence of bovine dermatophilosis in Andhra Pradesh. Int. J. Food Agri. Vet. Sci., 5 (2), 64-71.

Thrusfield, M., 2005. Veterinary Epidemiology, $3^{\text {rd }}$ edition, Singapore, Blackwell Science Ltd: Oxford, UK, Pp, 181-189.

Woldemeskel, M. and Taye, G., 2002.Prevalence of bovine dermatophilosis in tropical high land region of Ethiopia.Trop. Anim. Hlth. Prod., 34 (3),189-194.

Woldemeskel, M., 2000. Dermatophilosis: A threat to livestock production in Ethiopia. Dtsch Tierarztl Wschr, 107, 144-146.

Yeruham, I., Elad, D. and Nyska, A., 1995. Skin disease in a merino sheep herd related to an excessively rainy winter in a Mediterranean climatic zone. J. Vet. Med., 42, 35-40. 